\title{
ANALISIS STRATEGI PEMASARAN PEMBIAYAAN AKAD MUDHARABAH PADA LKMS (BPRS AL SALAAM KC. CIBINONG)
}

\section{ANALYSIS OF MARKETING STRATEGY OF AKAD MUDHARABAH FINANCING IN LKMS (BPRS AL SALAAM KC. CIBINONG)}

\author{
Siti Saadah'a , Metti Paramita², Hj Afiaty Kurniasih ${ }^{3}$ \\ ${ }_{1}^{1}$ Program Studi Perbankan Syariah Fakultas Ekonomi Islam Universitas Djuanda, Jl. Tol Ciawi No. 1, \\ Kotak Pos 35 Bogor 16720. \\ ${ }^{2}$ Program Studi Perbankan Syariah Fakultas Ekonomi Islam Universitas Djuanda, Jl. Tol Ciawi No. 1, \\ Kotak Pos 35 Bogor 16720 \\ ${ }^{3}$ Program Studi Perbankan Syariah Fakultas Ekonomi Islam Universitas Djuanda, Jl. Tol Ciawi No. 1, \\ Kotak Pos 35 Bogor 16720. \\ aKorespondensi: Siti Saadah, E-mail: saadah.siti2310@gmail.com
}

\begin{abstract}
This study aims to determine the model of marketing strategy development on the financing of mudharabah contract in BPRS Al Salaam KC. Cibinong. The method used in this research is descriptive analysis of transcendental phenomenology. Based on the result of research, it is concluded that in the development of starategi marketing of financing of mudharabah contract, bprs use $4 \mathrm{P}$ concept that is Product, Price, Place and Promotion. Marketing strategy is done with the concept of this 4P, BPRS make a way to make product innovation in accordance with the needs of the community, namely canvasing with the event jum'at blessing.
\end{abstract}

Keyword: Strategy, Marketing, Financing of mudharabah contract

\section{ABSTRAK}

Penelitian ini bertujuan untuk mengetahui model pengembangan strategi pemasaran pada pembiayaan akad mudharabah di Bprs Al Salaam KC. Cibinong. Metode yang digunakan pada penelitian ini yaitu analisis deskriptif fenomenologi transendental. Berdasarkan hasil penelitian, disimpulkan bahwa dalam pengembangan starategi pemasaran pembiayaan akad mudharabah, bprs menggunakan konsep 4P yaitu Product, Price, Place dan Promotion. Strategi pemasaran yang dilakukan dengan konsep 4P ini, Bprs melakukan cara dengan membuat inovasi produk sesuai dengan kebutuhan masyarakat, yaitu kanvasing dengan event jum'at berkah.

Kata Kunci : Strategi, Pemasaran, Pembiayaan akad mudharabah

Siti Saadah. 2020. Analisis Strategi Pemasaran Pembiayaan Akad Mudharabah Pada LKMS. Jurnal Nisbah 6 (2): 86-98.

\section{PENDAHULUAN}

Perkembangan keuangan syariah yang semakin pesat saat ini dapat membuka peluang untuk instansi mengembangkan usaha dengan prinsip syariah, hal ini terbukti dengan perkembangan lembaga keuangan berbasis syariah yang semakin cepat seperti perbankan syariah (Juliani, 2012).
Bersumber pada Undang-Undang nomor 10 Tahun 1998 yang telah disetujui sebagai landasan dan pengaturan mengenai perbankan syariah yang kini telah dirubah lebih spesifik dalam Undang-Undang terbaru yaitu UndangUndang nomor 21 Tahun 2008 tentang Perbankan Syariah. Hal yang diatur secara jelas dalam Undang-Undang tesrsebut 
adalah mengenai landasan hukum dan jenis-jenis usaha yang dapat diaplikasikan oleh bank syariah.

Undang-Undang tersebut juga mengarahkan kepada pembukaan cabang syariah oleh bank-bank konvensional atau bahkan mengganti total kegiatan operasional menjadi bank syariah (Arfiani \& Mulazid, 2017). Berdirinya Bank Muamalat Indonesia (BMI) menginisiasi pendirian lembaga keuangan berbasis syariah dan saat ini perkembangannya mulai pesat sehingga menjadi peluang untuk berdirinya bank-bank dengan prinsip syariah.

Namun operasionalisasi BMI belum dapat terjangkau oleh UMKM, kemudian terwujud usaha untuk mendirikan bank dan lembaga keuangan mikro, seperti Bank Pembiayaan Rakyat Syariah (BPRS) dan Baitul Maal wat Tamwil (BMT) yang bertujuan menangani kendala operasionalisasi tersebut. BPRS Al Salaam Amal Salman KC Cibinong sebagai lembaga perbankan syariah mulai beroprasional sejak tahun 1991.

Prinsip pendirian yaitu menopang perekonomian masyarakat melalui pelayanan lembaga keuangan bagi masyarakat ekonomi menengah, dan menyediakan pelayanan perbankan sesuai syariat Islam dan dikelola dengan prinsip ekonomi syariah yaitu, keterbukaan, kesetaraan serta keadilan bagi hasil antara nasabah dan pihak bank. Pada kenyataannya para pengusaha kecil dan menengah ternyata lebih mudah dijangkau dan tetap dapat berkembang dalam kondisi krisis sekalipun sehingga tetap dapat memberikan keuntungan bagi bank. Masalah yang sering terjadi oleh pengusaha kecil dan menengah pada umunya ialah kurangnya dukungan permodalan.

Maka disini peran BPRS yang sangat diandalkan untuk menanggulagi masalah tersebut, karena BPRS memfasilitasi permodalan dalam usaha kecil dan menengah. Dengan begitu agar pengusaha kecil dan menengah dapat merasakan fasilitas yang telah disediakan BPRS, maka BPRS menurunkan tugas pada bagian marketing untuk memasarkan produk dan menawarkan produknya agar dapat menanggulangi masalah yang dihadapi oleh pengusaha kecil dan menengah, usaha yang dilakukan marketing tersebut agar produk dapat sampai ke masyarakat yakni dengan cara melakukan berbagai macam cara pemasaran, mulai dari penyebaran brosur, sistem jemput bola dengn nasabah, pemasangan iklan spanduk, sampai dengan mengadakan event dengan maksud untuk memperkenalkan produk kepada masyarakat pada umumnya.

Penekanan perkenalan serta penawaran produk disini untuk menanggulangi masalah kurangnya permodalan pada usaha kecil dan menengah yaitu penawaran Akad-akad kerjasama seperti mudharabah dan musyarakah sebagai penanggulangannya. Akad kerjasama ini merupakan salah satu produk yang dapat mendongkrak pertumbuhan perbankan syariah (Islami, 2018).

Disini marketing menurunkan strategi nya dalam pemasaran produk ini, yaitu dengan aspek strategi segmentasi pasar (segmentation), target pasar yang tepat (targeting) dan penentuan posisi (positioning) harus dipersiapkan untuk menarik nasabah (Purnama Sari, 2011). Namun dalam persaingan bisnis ini tugas marketing juga bukan hanya menjelaskan produk kepada nasabah dan menarik nasabah, didalam strategi pemasaran marketing juga harus mampu bersaing ketat dengan perusahaan lainnya untuk mencapai keberhasilan perusahaan.

Dalam kontek pemasaran ini, marketing dapat melakukan upaya pemasaran dengan cara bersifat media seperti penyebaran brosur,iklan,serta pemasangan banner dan bersifat non media seperti informasi dari mulut ke mulut, atau informasi dari nasabah lama atas kepuasan pelayanan BPRS. Dalam 
promosi penjualan ini dilakukan dalam jangka pendek.

Karena dari persaingan ketat global yang melakukan promosi atas produknya juga, maka konsumen telah menjadi terbiasa dengan promosi penjualan sehingga tanggapan konsumen atas aksi promosi penjualan akan cenderung sama. Oleh karena itu yang perlu dilakukan adalah memperkenalkan produk dengan design baru untuk membangun merek dan penguatan pada pesan iklan dan citra perusahaan.

Sehingga promosi yang dilakukan dapat mendorong kepada konsumen untuk melakukan pembelian atau penggunaan pada akad yang ditawarkan (Hasan, 2010)

\section{MATERI DAN METODE}

\section{Strategi}

Dalam Kamus Istilah Manajemen, strategi adalah suatu rancangan yang cermat perihal kegiatan untuk mencapai target khusus dan saling berkaitan dalam waktu dan ukuran. Namun strategi dalam sebuah perusahaan yaitu sebagai salah satu faktor terpenting agar suatu perusahaan dapat beroperasi dengan baik.

Dimana strategi ini menggambarkan kepada aspek bisnis yang mengikuti pada lingkungan yang telah dipilih dan merupakan arah untuk mendistribusikan sumber daya usaha suatu organisasi (Noer Riadho, 2010). Dari definisi tentang Strategi diatas dapat disimpulan tentang Strategi yaitu:

a. Strategi merupakan suatu kesatuan rencana terpadu yang diperlukan untuk mencapai tujuan organisasi.

b. Dalam menyusun strategi perlu dihubungkan dengan lingkungan organisasi, sehingga dapat disususn kekuatan strategi organisasi.

c. Dalam perencanan tujuan organisasi perlu alternative strategi yang dipertimbangkan dan harus dipilih.

d. Strategi yang dipilih akan diimplementasikan oleh organisasi dan akhirnya membutuhkan evaluasi terhadap strategi tersebut.

Suatu organisasi akan lebih efektif jika telah menyusun strategi dibandingkan dengan organisasi yang tidak menyusun strategi. Hal ini disebabkan strategi adalah kacamata yang bermanfaat untuk memonitori apa yang dikerjakan dan apa yang sedang berjalan didalam suatu organisasi, dapat memberikan sumbangan terhadap kesuksesan organisasi atau malah mengarahkan kepada kegagalan organisasi (Purnama Sari, 2011).

\section{Strategi dalam Perspektif Islam}

Pada masa Rasulullah proses penyusunan strategi telah sering dipakai untuk berdakwah dan memperluas kekuasan atau bahkan peperangan. Dengan hal itu dapat dikatakan bahwa secara tidak langsung Islam telah mengajarkan umatnya untuk merangkai dan menjalankan sebuah strategi agar dapat tercapainya tujuan dari organisasi. Maka strategi dalam sebuah organisasi yang dimaksud untuk pencapaian suatu tujuan dengan penggunaan sumberdaya organisasi. Esensi dari pengaplkasian sumber daya organisasi juga merupakan amal perbuatan SDM organisasi yang berkepentingan (Prasetya, Azizah, \& Shofiyah, 2016).

\section{Pemasaran}

Pemasaran sebagai fungsi penting untuk perusahaan karena merupakan suatu faktor yang sangat berperan dalam siklus bermula dan berakhirnya dalam kebutuhan konsumen, setiap perusahaan berusaha untuk memenuhi kebutuhan konsumen dengan memproduksi dan memasarkan produk atau jasa (Entaresmen, 2016). Dimana artinya perusahaan harus dapat menginterpretasikan kebutuhankebutuhan konsumen dan mencampurkannya dengan data pasar. Pemasaran adalah perencanaan dan pelaksanaan dari konsep perusahaan, penentuan harga, promosi, pendistribusian barang atau jasa, dan gagasan untuk membentuk pertukaran 
dengan suatu organisasi yang dituju, guna memuaskan pelanggan dan perusahaan sehingga penjualan produk dan jasa tercapai dengan cepat (Fawaid, 2017).

Menurut (Kasmir, 2014:216) dalam konsep pemasaran ada 4P yaitu Product (Produk), Price (Harga). Place (Tempat/Lokasi), Promotion (Promosi).

a) Product (Produk)

Produk dapat diartikan sebagai sesuatu yang dapat dijadikan pemenuh kebutuhan pasar dan keinginan pelanggan. Setelah menganalisa atas kebutuhan dan keinginan pasar, maka suatu produk dapat dikembangkan untuk memenuhi segala permintaan pasar. Dalam praktiknya produk terdiri dari dua jenis yaitu produk yang berwujud (fisik) dan tidak berwujud (non fisik).

Produk fisik adalah produk yang dihasilkan atau diproduksi oleh distributor kemudian dapat dipromosikan agar sampai ke pasaran, sedangkan kalau produk non fisik adalah penawaran atas jasa yang diberikan kepada pelanggannya dengan harga atau upah yang diberikan dari jasanya tersebut. Konsep pemasaran pada produk adalah suatu wujud atas barang atau jasa sebagai objek yang akan di pasarkan atau dijual.

b) Price (Harga)

Konsep pemasaran pada harga adalah sebagai penentu atas harga penjualan dengan memperhatikan biaya produksi dan keuntungan Mengingat bahwa harga sangat berperan dalam penentuan laku atau tidaknya produk atau jasa maka harga merupakan aspek yang sangat penting untuk diperhatikan. Namun strategi pemasarannya dalam penetuan harga atas produk dapat melakukan suatu kebijakan harga dengan menyangkut penetapan jumlah pemotongan harga, seperti mark-up (berapa tingkat persentase kenaikan harga atau tingkat keuntungan yang diinginkan), mark-down (berapa tingkat persentase penurunan harga), potongan harga (discount) dan sebagainya.

c) Place (Lokasi)

Pemilihan lokasi harus strategis karena lokasi menentukan minat konsumen atau nasabah untuk berhubungan dengan pasar atau bank karena apabila salah menganalisis lokasi akan mengakibatkan menurunkan minat nasabah seperti kalau lokasinya jauh dari pemukiman, atau keramain kota maka nasabah akan susah mengaksesnya dan berakibatkan meningkatkan pengeluaran biaya transportasinya.

Dalam konsep pemasaran pada place ini ada 3 hal yang harus diperhatikan yaitu pertama sistem transportasi perusahaan yaitu dilihat pada keputusan atas pemilihan alat transportasinya dengan penentuan jadwal pengiriman dan pertimbangan atas rute yang akan ditempuh. Kedua sistem penyimpanan, hal ini sangat perlu diperhatikan untuk produksi fisik sepeti menetukan lokasi gudang penyimpanan barang baik itu jenis material maupun yang lainnya.

Ketiga pemilihan saluran distribusi yaitu melihat bagaimana agar produk dapat sampai kepasaran atau kekonsumen dengan memperhatikan sasaran target untuk pemilihan tempat.

d) Promotion (Promosi)

Kegiatan promosi merupakan kegiatan sangat penting juga dimana dalam hal ini setiap bank atau perusahaan berusaha untuk mengenalkan serta mengajak target agar dapat menerima atas seluruh produk dan jasa yang dimilikinya baik langsung maupun tidak langsung dengan tujuan agar konsumen mengetahui produknya dan pada akhirnya memutuskan untuk membeli produknya. Aktivitas promosi ni dapat dilakukan seperti membuat iklan, 
personal seling, promosi penjualan dan publisitas.

\section{Pemasaran dalam Perspektif Islam}

Menurut Herman Kartajaya salah seorang pakar dibidang pemasaran dan syariah, mendefinisikan dalam perspektif Islam pemasaran merupakan suatu penerapan disiplin strategi yang condong pada proses penciptaan, penawaran, dan perubahan nilai dari satu penggagas kepada para pemegang sahamnya, yang dalam seluruh prosesnya sesuai dengan nilai dan prinsip syariah (Rivai, 2012).

\section{Pembiayaan}

Menurut UU No. 21 Tahun 2008 tentang Bank Syariah pasal 1 butir 7, bank syariah adalah Bank yang mengoperasikan kegiatan usahanya berdasarkan prinsip syariah, dilihat dari jenisnya bank syariah terdiri atas bank umum syariah dan bank perkreditan rakyat syariah, sedangkan pembiayaan menurut UU Republik Indonesia No. 21 Tahun 2008 pasal 1 ayat (25) yang dimaksud pembiayaan adalah penyediaan atau tagihan yang dipersamakan dengan itu berupa transaksi bagi hasil dalam bentuk mudharabah dan musyarakah (Muklis, Fauziah Siti. 2015).

\section{Pengertian Pembiayaan Mudharabah}

Pembiayaan

Mudharabah

merupakan suatu perwujudan keadilan bagi masyarakat dalam sistem bagi hasil atas penerapan prinsip Ekonomi Islam (Mauludi AC, 2015).

Bank syariah harus mengembangkan prinsip utamanya berkaitan dengan pengelolaan dana dimana bank syariah harus mampu memberikan bagi hasil yang lebih besar dibandingkan dengan suku bunga yang berlaku di konvensional kepada deposan (penyimpan dana), dan mampu menarik bagi hasil yang lebih rendah dari debitur dibandingkan bunga yang berlaku di bank konvensional (Susana Emi, Prasetyanti Annisa. 2011).

Pengertian Pembiayaan Mudharabah Menurut Abdurrahman al-Jaziri mudharabah adalah cerminan dari harta yang diberikan kepada seseorang dari orang lain yang dipakai sebagai modal usaha dimana perolehan keuntungan akan dibagi antara kedua belah pihak tersebut sesuai dengan nisbah yang telah disepakati pada akad ( Dwi, Fransisca, Zahroh 2014), dan jika mengalami kerugian maka akan ditanggungkan oleh pemilik modal dengan alasan bukan sesuatu kerugian yang disengaja (Karim, 1997).

Sedangkan menurut fatwa Dewan Syariah MUI No. 07/DSN-MUI/IV/2006. Pembiayaan Mudharabah adalah penyaluran pembiayaan oleh LKS (Lembaga Keuangan Syariah) kepada pihak lain untuk suatu usaha yang produktif, dimana LKS sebagai Shahibul maal (pemilik dana) membiayai kebutuhan suatu proyek (usaha) 100\%, sedangkan pengusaha (nasabah) berperan sebagai mudharib atau pengelola usaha.

Jadi definisi yang representatif sebagai jalan tengah kelengkapan definisi dari beberapa ahli maupun mazhab menurut penulis, mudharabah adalah suatu akad (kontrak) kerjasama antara pemilik modal dengan pengelola dimana keuntungan dari usaha tersebut akan dibagi menurut kesepakatan bersama.

\section{Dasar Hukum Akad Mudharabah}

Secara umum, landasan dasar Syariah Mudharabah lebih mencerminkan anjuran untuk melakukan usaha (Antonio, 2001). Hal ini telah tampak dalam Firman Allah QS. Al-Muzammil:20:

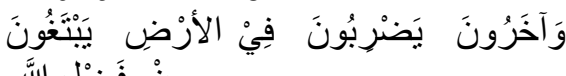

$$
\begin{aligned}
& \text { مِنْ فَضْلِ اللَّهِ }
\end{aligned}
$$

Artinya: :....Dan orang-orang yang berjalan dimuka bumi mencari sebagian karunia Allah,,", (QS. Al-Muzammil:20)

Berdasarkan Surat tersebut, yang menjadi wujud atau argument dari surat Al Muzammil, karena didalam nya terdapat kalimat "yadhribuuna fil'ardh" yang mengandung arti bahwa dalam mencari karunia Allah dapat dilakukan dengan mudharabah yang bekerjasama mencari rezeki yang ditebarkan Allah SWT dimuka bumi dan hukumnya adalah boleh 
dan sah, karena sesuai dengan prinsipprinsip syariah dengan tidak merugikan salah satu pihak, dalam arti salah seorang diantara yang berakad tidak berbuat curang untuk mendapatkan nisbah yang tidak sesuai kesepakatan.

\section{Problematika Pembiayaan Akad Mudharabah}

Secara umum perbankan syariah memiliki dua peran, yaitu pada sisi penghimpunan dana masyarakat, bank bertindak sebagai pengelola dana (mudharib) melalui akad mudharabah dengan nasabah pemilik tabungan mudharabah dan deposito mudharabah sebagai pemilik dana (shahibul maal), dan dilihat pada sisi penyaluran dana kepada masyarakat, bank bertindak sebagai pemilik dana (shahibul maal) dan nasabah sebagai pengelola dana (mudharib) dengan melalui akad mudharabah dan musyarakah (Chairul Hadi, 2011).

Ketika menjadi mudharib resiko yang akan mungkin dihadapi oleh bank adalah kerugian usaha bank dan hal ini akan berdampak kepada pemilik dana (nasabah). Akan tetapi, karena pengawasan bank sentral yang ketat kepada sektor perbankan maka resiko ini cenderung lebih kecil. Dalam rangka melindungi pemilik dana (nasabah), maka setiap sektor perbankan wajib mengikuti berbagai aturan bank sentral dan pemerintah (A, Karnaen. 2002).

Pada saat bank bertindak sebagai pemilik dana (shahibul maal), resiko yang dihadapi oleh bank akan lebih besar disebabkan belum adanya standar biaya untuk berbagai jenis usaha yang beragam. Saat ini standar biaya yang diberlakukan terbatas pada upah minimum regional (UMR) sedangkan biaya operasional lainnya belum ada. Selain itu, tidak adanya lembaga yang membina dan mengawasi nasabah yang berperan sebagai mudharib.

Dengan demikian resiko yang dihadapi dalam bentuk penyertaan modal terutama pada akad kerja sama mudharabah ini dianggap lebih besar dibandingkan dengan usaha bank berbentuk pembiayaan jual-beli (perdagangan) melalui akad murabahah, salam, istishna, ijarah. Resiko pada akad mudharabah ini, bank menyediakan $100 \%$ kebutuhan modal usaha sedangkan pihak mudharib menyediakan jasa pengelola usaha, karena sebagai sisi pemberi modal bank tidak boleh intervensi dalam usaha mudharib.

Hasil yang didapatkan dari usaha yang dikelola dibagihasilkan antara bank dengan mudharib dengan nisbah yang telah disepakati. Jika terdapat kerugian, maka kerugian uang tersebut akan ditanggung seluruhnya atau sebagiannya oleh bank, sedangkan pengelola tidak mendapatkan bayaran dari usahanya. Penyaluran dana kepada masyarakat lebih banyak berbentuk pembiayaan perdagangan (murabahah) daripada berbentuk modal penyertaan (mudharabah dan musyarakah) karena tingginya resiko.

Padahal yang memiliki dampak langsung kepada pertumbuhan ekonomi berupa tumbuhnya peluang usaha baru, kesempatan kerja baru dan peningkatan pendapatan penduduk adalah pembiayaan dalam bentuk kerjasama ini baik itu mudharabah maupun musyarakah (Chairul, 2011). Tingkat tingginya resiko ini masih sangat menjadi pertimbangan penting kenapa bank syariah masih kurang tertarik untuk memberikan pembiayaan mudharabah, karena pada zaman sekarang masih sangat sulit mencari pengusaha yang jujur dan amanah (perilaku moral hazard nasabah).

\section{Jenis Penelitian}

Dalam suatu penelitian sangatlah dibutuhkannya metode yang mendukung untuk memperoleh hasil yang sempurna (Maulida,2015). Adapun jenis penelitian pada penelitian ini adalah deskripsikualitatif yaitu jenis penelitian yang menggambarkan suatu keadaan objek atau peristiwa untuk mengambil kesimpulankesimpulan yang berlaku secara umum (Paramita, 2017. V0l 3, N0. 2 Hal 496). 
Berdasarkan hal tersebut, maka deskriptif kualitatif ini menggunakan pendekatan fenomenologi transendental. metode ini ditujukan untuk mengetahui dan menjelaskan fenomena tentang strategi pemasaran akad mudharabah pada BPRS Al Salaam, dengan menganalisis fokus pengembangan strategi pemasaran yang dilakukan oleh BPRS Al Salaam.

Fenomenologi transendental ini digunakan untuk memahami kejadian dari pengalaman-pengalaman hidup beberapa orang dan interpretasi dunia sebagai acuan untuk konsep yang akan diteliti dalam mengolah data yang didapatkan dari lapangan, sehingga akan tertata jelas dalam membuat kesimpulan. (Sugiyono, 2013)

\section{Populasi dan Sampel}

Populasi adalah kawasan penggabungan yang meliputi objek/subjek yang mempunyai karakteristik dan kualitas tertentu yang ditentukan untuk dipelajari serta diambil kesimpulannya (Sugiyono, 2013).

Sampel adalah suatu cara pengumpulan data yang sifatnya tidak menyeluruh, yaitu tidak mencangkup seluruh objek penelitian (populasi) akan tetapi sebagiannya saja dari populasi (Sugiyono, 2014).

\section{Objek dan Lokasi Penelitian}

Objek penelitian ini Kepala Cabang dan karyawan bagian marketing dan customer service Kantor Cabang Cibinong Komplek Ruko Mayor Oking 1 No. A10, Jl. Raya Mayor Oking Jaya Atmaja, Cirimekar, Cibinong Bogor, Jawa Barat 16917.

\section{Sumber Data}

Pada penelitian ini terdiri dari dua sumber data yang diaplikasikan, yaitu data primer dan data sekunder.

1. Data primer merupakan data pokok yang menjadi sumber dalam penelitian. Data ini diperoleh langsung dari sumbernya dilakukan melalui wawancara, observasi, dan alat-alat lainnya (Munawar, 2015). Data primer dalam penelitian ini diperoleh dari responden yaitu hasil wawancara dengan kepala cabang BPRS AlSalaam.

2. Data sekunder adalah data pendukung yang diperolehnya bukan dari sumbernya langsung, tetapi dari sumber lain seperti buku, jurnal, internet dan bahan pustaka lainnya yang berkaitan dengan penelitian. Data sekunder dalam penelitian ini adalah jurnal, buku yang berkaitan dengan tinjauan pustaka.

\section{Teknik Pengumpulan Data Interview}

Teknik interview adalah salah satu pengumpulan data dengan mencari informasi dengan cara berhubungan langsung dengan narasumber dengan cara percakapan yang mengandung unsur pertanyaan (Kartono, 1990). Narasumber dalam penelitian ini adalah Kepala Cabang BPRS Al-Salaam KC Cibinong.

\section{Dokumentasi}

Teknik dokumentasi yang digunakan dalam penelitian ini adalah mencari data mengenai hal atau variable yang berupa catatan atau benda-benda tertulis seperti buku, jurnal, skripsi, dan lain sebagainya yang terkait dengan penelitian ini (Abbudin, 1999). Dimana peneliti menggunakan teknik dokumentasi ini untuk memperoleh data yang mencatat untuk laporan kejadian-kejadian baik masa sekarang maupun masa lampau yang berisi pandangan atau pemikiran manusia.

\section{Observasi}

Teknik observasi ini dimana peneliti melakukan pengamatan yang sistematik baik secara langsung maupun tidak langsung. Secara umum observasi dapat dilaksanakan dengan partisipasi berarti peneliti menjadi ikut serta dalam suatu kegiatan. Dimana observasi ini untuk memperoleh data yang lebih lengkap, akurat dan validitasnya terjamin. Namun, pada penelitian ini menggunakan metode non participant observation yaitu peneliti tidak melibatkan diri menjadikan bagian dari sosial limgkungan, melainkan hanya mengamati bagaimana proses strategi 
yang dilakukan untuk memsarkan pembiayaan akad mudharabah ini (Suprapto,2017).

\section{Teknik Analisis Data}

Setelah data terkumpul dari berbagai hasil pengumpulan data, maka peneliti mengadakan analisis data yaitu proses penyederhanaan data ke dalam bentuk yang lebih mudah dibahas dan diinterprestasikan (J.Moleong, 2001). Agar dalam menganalisa data dapat dilaksanakan dengan baik, maka harus sesuai dengan langkah-langkah atau prosedurnya. Diantaranya

1. Mencatat sebuah data yang tersedi dari berbagai sumber yaitu: transkip wawancara, pengamatan yang sudah dituliskan dalam catatan lapangan, dokumentasi resmi dan bahan-bahan yang lain dikumpulkan untuk meningkatkan pemahaman terhadap bahan-bahan tertentu.

2. Mengumpulkan, memilah-milah data dengan membuat rangkuman yang inti dari hasil wawancara, pengamatan yang sudah ditulis dalam catatan lapangan, dokumentasi resmi.

3. Menyusun dalam satuan-satuan yang kemudian dikategorikan pada langkah berikutnya.

4. Melakukan pemeriksaan keabsahan data.

5. Membuat kesimpulan berdasarkan data yang diperoleh dan dari pemer iksaan keabsahan data.

\section{HASIL DAN PEMBAHASAN}

\section{Strategi Pemasaran Produk Pembiayaan pada BPRS}

Dunia persaingan dalam perbankan saat ini semakin ketat, dengan begitu setiap perusahaan pasti melakukan banyak cara untuk memperkenalkan setiap produk yang dimilikinya dan memasarkannya serta tetap mempertahankan kepercayaan nasabah dengan memberikan pelayanan yang baik. Berbagai macam cara banyak dilakukan untuk memperkenalkan, memasarkan dan mempromosikan produknya agar sampai ke tangan nasabah baik dengan cara media seperti

1. Iklan

Pada strategi promosi dengan iklan, dimana BPRS melakukan berbagai macam iklan seperti di media sosial, website resmi, dan lainnya. dengan iklan BPRS mengenalkan produk kepada masyarakat dengan sistem perkembangan zaman, dimana iklan ini dapat dilihat, dikunjungi websitenya tanpa harus nasabahnya langsung pergi ke tempat, melainkan dapat dilakukan dirumah, kantor, dan dimana pun berada dengan membuka dan mengunjungi sosial media atau website resmi milik BPRS.

2. Penyebaran Brosur

Strategi promosi dengan cara penyebaran brosur ini guna menjelaskan kepada nasabah tentang produk serta definisi produk yang dimiliki oleh BPRS, dimana penyebaran brosur biasa dilakukan pada BPRS di wilayah-wilayah tertentu yang ramai dan banyak dikunjungi orang, seperti masjid, sekolah, pasar, dan lainnya.

3. Pemasangan Banner

Dengan memasangkan banner seperti di pinggir jalan raya dengan maksud untuk memperkenalkan kepada masyarakat atas identitas diri BPRS.

4. Non Media atau dari Mulut ke Mulut.

Strategi dari mulut ke mulut ini BPRS sangat mengharapkannya kepada nasabah lama, dimana nasabah lama ini agar memberikan dan menyebarkan informasi tentang kepuasan atas pelayan BPRS kepada masyarakat. Oleh karena itu BPRS harus selalu menjaga loyalitas pelayannya kepada setiap nasabahnya guna untuk menjaga kerja sama dalam penyebaran informasi seperti ini.

Selain 4 hal diatas dalam penyebaran bosur dan menarik nasabah baru BPRS memiliki strategi dengan cara kanvasing yaitu dengan melakukan penyebaran brosur ke beberapa tempat sasaran yang 
tempatnya sesuai dengan kriteria yang sudah ditentukan, dimana kanvasing ini adalah event dalam memasarkan produknya yaitu Jum'at berkah adalah dengan datang ke masjid-masjid tertentu yang sudah sesuai dengan sasaran kriteria yang ditentukan BPRS dengan melakukan memberikan peci pada peserta sholat Jum'at dengan kriteria yang dipilih, lalu orang yang mendapat peci tersebut diminta datanya yaitu KTPnya dan nomer handphone, isi formulir lalu tawarkan produk-produk bank. Kalau mmang cocok, maka akan ditindak lanjuti yaitu melakukan BI Checking atau SID (Sistem Informasi Debitur) jadi melihat apakah nasabah ini memiliki riwayat yang buruk atau tidak saat melakukan pengajuan pembiayaan. Event yang dilakukan oleh BPRS al salaam ini bukan hanya jum'at berkah, adapun event mencuci motor gratis dan service motor gratis di hari weekend yaitu nasabah pembiayaan kredit motor di bolehkan mencuci motornya dengan gratis dan melakukan service motor gratis, guna untuk menjaga hubungan baik dengan nasabahnya.

\section{Strategi Pemasaran Produk Pembiayaan Akad Mudharabah}

Akad mudharabah adalah akad kerjasama yang dipromosikan oleh BPRS dengan target sasaran tertentu yakni BPRS menargetkan kepada masyarakat yang memiliki usaha proyek dengan jangka waktu pendek hanya sekitar 3 sampai 6 bulan saja. Cara BPRS menarik minat nasabah untuk dapat penggunaan akad mudhrabah ini adalah dengan memberikan keluasan dalam penggunaan modalnya. Dalam arti setiap pembiayaan akad mudharabah per bulannya tidak membayar angsuran pokoknya, melainkan hanya setoran nisbah bagi hasil yang telah ditetapkan pada awal akad, dan pembayaran pokok itu dilakukan pada bulan akhir masa jatuh tempo akad dengan tujuan agar setiap bulan nasabah tidak memikirkan angsuran untuk pokoknya agar nasabah dapat fokus mengelola dananya untuk modal usaha.
Jadi, BPRS menawarkannya kepada pemilik kontraktor renovasi rumah, proyek pembuatan papan petunjuk arah jalan dan lainnya. Dengan begitu BPRS melakukan pendekatan pada masyarakat pemilik proyek dan menawarkan produk pembiayaan akad mudharabah ini dengan jangka waktu pendek. Dengan menawarkan akad mudharabah, akad kerjasama ini dapat digunakan dengan ketentuan nisbahnya berdasarkan negosiasi dan kesepakatan antara kedua belah pihak.

Pada penelitian ini dalam pengembangan strategi pemasaran pembiayaan akad, peneliti menggunakan rumus $4 \mathrm{P}$, dimana strategi 4P tersebut adalah:

1. Product

Dalam strategi pemasaran pembiayaan akad mudharabah, melihat bagaimana strategi yang dilakukan BPRS dalam mendesain produknya agar dapat dikenal oleh masyarakat dan diterima oleh masyarakat yakni dimana hal yang dilakukan BPRS Al Salaam adalah dengan cara mempromosikan seperti membagikan brosur, pemasangan banner, dan kegiatan/event yang bersangkutan dengan kebutuhan BPRS. Dimana strategi dalam produk ini yaitu menunjukan sasaran kepada nasabah yang umumnya bukan pedagang melainkan nasabah pemilik proyek usaha baik itu dalam bentuk instansi ataupun perorangan, peran BPRS disini memasarkan produk pembiayan akad mudharabah dengan jangka pendek dengan setiap cicilan pokok perbulan dibayar diakhir guna untuk memfokuskan nasabah dalam penggunaan modalnya disetiap bulan.

2. Place

Place atau tempat adalah strategi pemasaran yang dilakukan bagaimana agar produk dapat sampai ke konsumen atau nasabah. Dalam penelitian ini hal yang dilakukan pada prinsip place adalah dimana BPRS menentukan tempat untuk dijadikan 
target sasaran yakni dengan memilih area untuk melakukan kanvasing, dimana area-areanya yang telah dipilih sesuai dengan kriteria yang telah ditentukan oleh pihak BPRS. Selain melakukan kanvasing dengan penyebaran brosur dan event lainnya, BPRS juga menjaga hubungan baik dengan nasabah guna agar nasabah lama dapat menyebarkan informasi yang baik tentang kepuasan pelayanan BPRS, hal demikianlah dalam strategi pemasaran pada prinsip place yang dilakukan oleh BPRS. Namun dalam penentuan tempat untuk melakukan kanvasing biasanya mengalami sedikit kesulitan, seperti susahnya perijinan pada wilayah tertentu itu yang menjadi hambatan dalam strategi pemasaran dalam prinsip place ini. Oleh dari itu, untuk mensiasatinya BPRS banyak melakukan komunikasi dengan berbagai macam wilayah seperti area wilayah masjid-masjid pabrik, wilayah sekitar perkantoran, wilayah pasar, dan wilayah-wilayah area kriteria BPRS guna menjaga hubungan baik agar dapat diterima oleh masyarakat.

\section{Price}

Strategi pemasaran prinsip price ini adalah bagaimana tentang kesepakatan nisbah bagi hasil yang telah ditetapkan oleh BPRS. Dalam penentuan nisbah bagi hasil ini, BPRS biasanya bernegosiasi dengan calon nasabah pengajuan pembiayaan, agar keduanya sepakat atas nisbah yang telah ditentukan pada awal akad. Dalam strategi pemasaran pada price ini dimana yang menjadi unggul pada BPRS adalah selama waktu pembiayaan tersebut nasabah tidak mengembalikan pokok hanya bagi hasilnya saja, guna untuk memfokuskan nasabah dalam penggunaan modalnya. Ketika bulan akhir jatuh tempo biasanya 3-6 bulan maka pada bulan terakhir ini nasabah mengembalikan seluruh pembiayaan dan bagi hasil perbulan terakhir jatuh temponya. Disinilah hal yang membuat menarik nasabah dalam strategi pemasaran place pada akad mudharabah.

\section{Promotion}

Strategi BPRS dalam memperkenalkan setiap produk yang dimilikinya agar dapat diterima oleh konsumen atau nasabah, dimana BPRS melakukan promosi dengan cara agar dapat menarik minat nasabah. Dalam promosi pembiayaan produk akad mudharabah biasanya BPRS menargetkan sasarannya kepada calon nasabah atau masyarakat yang memiliki usaha proyek baik itu intansi atau perseorangan, tidak ada cara khusus memang dalam pemasaran produk pembiayaan akad mudharabah, namun biasanya BPRS memiliki target nasabah untuk ditawarkan produk pembiayaan akad mudharabah. Dimana BPRS melihat dari riwayat usaha yang dimiliki oleh nasabah lama atau calon nasabah pengajuan pembiayaan dengan sekiranya masuk pada kriteria nasabah sasaran maka BPRS mempromosikan dan menawarkan produk pembiayaan akad mudharabah.

\section{Persepsi Masyarakat Terhadap Pembiayaan Akad Mudharabah}

Pada umumnya, akad kerjasama seperti akad mudharabah ini jarang sekali dilirik oleh masyarakat atau calon nasabah. Padahal akad kerjasama ini merupakan tonggak ekonomi Islam yang mewakili prinsip Islam untuk mewujudkan keadilan masyarakat dengan sistem bagi hasil. Masyarakat menganggap bahwa pembiayaan akad mudharabah ini prosesnya sulit untuk dilakukan, karena memang banyak beberapa proses yang harus lebih diteliti dan ditinjau oleh BPRS. Maka dengan demikian masyarakat mensiasati untuk penggunaan yang cepat dalam proses pembiayaan itu dengan akad-akad jual beli, padahal kalau dilihat 
dari segi latar belakang usaha yang dimiliki oleh masing-masing pada setiap nasabah itu akad kerjasama dapat lebih meringankan karena jangka pendek waktunya dan pengembalian pokok dilakukan pada akhir bulan jatuh tempo masa pembiayaan.

Analisis Penerapan Strategi Pemasaran Pembiayaan Akad Mudharabah di BPRS

Konsep pemasaran, dalam teorinya ada prinsip 4P. Konsep ini digunakan sebagai strategi dalam mengembangkan, mengenalkan dan memasarkan setiap produk atau jasa yang dimiliki oleh pihak produsen atau bank. Pada penelitian ini akan menganalisis apakah strategi pemasaran yang diterapkan oleh BPRS telah sesuai dengan teori pemasaran konsep 4P. Dimana dalam teori pemasaran $4 \mathrm{P}$ ini adalah Product, Place, Price, Promotion (Kasmir, 2014).

Setelah penulis melakukan analisis di BPRS Al Salaam ini, maka penulis menyatakan bahwa BPRS Al Salaam ini dalam mengembangkan produknya atau memasaran akadnya menggunakan prinsip 4P ini, apalagi dalam pemasaran akad mudharabah. Karena seperti hal nya diketahui bahwa akad mudharabah ini kurang diminati banyak masyarakat akibat prosesnya yang panjang sehingga dianggap terlalu sulit. Dengan penerapan prinsip 4P ini sebagai strategi pemasaran akad mudharabah, guna memperkenalkan kepada masyarakat sehingga dapat diminati oleh masyarakat untuk menggunakan akad mudharabah di BPRS.

Panjangnya proses dalam akad mudharabah ini karena resiko yang terkandung dalam akad mudharabah terbilang cukup tinggi diliat dari posisi bank sebagai shaibul maal, karena tidak ada lembaga yang menjamin atas kerugian yang akan dialami karena kelalaian dari mudharib karena semua kerugian akan ditanggung oleh pihak bank. Dengan begitu maka bank melakukan proses yang begitu detail guna menanggulangi resiko mendatang. Namun hal tersebut ternyata tidak dapat diterima baik oleh masyarakat, karena dengan perkembangan dunia yang semakin dewasa ini, masyarakat telah dimanjakan dengan kemudahan. Jadi saat masyarakat dihadapkan dengan sesuatu yang sedikit lebih merumitkan itu akan ditinggalkan.

Oleh karena itu pemasaran akad mudharabah ini harus sangat ekstra. Pada penelitian ini BPRS melakukan pemasarannya dengan cara berinovasi pada pemasaran promosi yang telah dilakukan, seperti:

a. Memberi jangka waktu pembiayaan tidak terlalu lama hanya kisaran jangka waktu 3bulan, 6bulan, dan paling lama sampai 12bulan. Pemberian penawaran jangka waktu prmbiayaan yang pendek tersebut disesuaikan dengan jangka waktu pemesanan konsumen kepada pemilik proyek (mudharib bank). Setelah proyeknya selesai dan telah dikerjakan maka mudharib pula harus menyelesaikan hutangnya kepada shahibul maal. Jadi setelah proyek mudharib selesai itu sudah tidak ada lagi harus memikirkan lagi beban hutang kepada shahibul maal

b. Tidak memberatkan untuk membayar pokok hutang pada setiap bulannya. BPRS setiap bulannya hanya menerima bagi hasil saja. lalu pokok hutang yang harus dibayar itu dilunasi pada angka waktu akhir bulan. Inovasi pemasaran ini dipilih BPRS sebagai menarik minat nasabah untuk memberikan kepuasaan dalam penggunaan dananya.

c. Pembagian atas bagi hasil yang telah didapatkan oleh mudharib itu dapat disetorkan ke bank dengan cara dijemput, dalam arti pihak bank yang akan ketempat nasaba pada jatuh tempo setiap bulannya jadi nasaba tidak perlu datang ke bank. Cara ini dipilih BPRS dalam memberikan pelayanan yang memuaskan kepada nasabahnya. 


\section{KESIMPULAN DAN IMPLIKASI}

Setelah melakukan penelitian mengenai "Model Pengembangan Strategi Pemasaran Pembiayaan Akad Mudharabah pada LKMS (BPRS Al Salaam KC. Cibinong)" maka terdapat beberapa kesimpulan dan implikasi dari hasil penelitian ini sebagai berikut:

a. Berdasarkan hasil analisis, strategi pemasaran pembiayaan akad mudharabah dilakukan dengan memberikan keluasan kepada nasabah untuk menggunakan modal usaha dengan tidak membayar pokok

\section{DAFTAR PUSTAKA}

Undang-Undang Nomor 10 Tahun 1998 Tentang Perubahan Atas UU No. 7 Tahun 1992 Tentang PERBANKAN

Undang-undang Nomor 21 Tahun 2008 Tentang Perbankan Syariah

Alhifni, Anas. Huda, Nurul. (2015). Kinerja LKMS Dalam Mendukung Kegiatan Ekonomi Rakyat Berbasis Pesantren (Studi Pondok Pesantren Darut Tauhid dan BMT Darut Tauhid). Jurnal Aplikasi Manajemen. Vol. 3, No. 4, Hal 601

Chairul Hadi, A. (2011). Problematika Pembiayaan Mudharabah Di Perbankan Syariah Indonesia. Jurnal Mashlahah, Vol.2, No.1

Chalifah, Ela. Sodiq, Amirus. ( 2015). Pengaruh Pendapatan Mudharabah Dan Musyarakah Terhadap Profitabilitas (Roa) Bank Syariah Mandiri Periode 2006-2014. Jurnal EQUILIBRIUM, Vol. 3, No.Hal 33

Dharmayanti, Diah. Suryawan, Sheehan. (2013). Analisa Hubungan Antara Experential Marketing, Customer Satisfaction Dan Customer Loyalty Cafe Nona Manis Grand City Mall Surabaya. Jurnal disetiap jatuh tempo, melainkan membayar kewajiban hutangnya pada akhir masa jatuh tempo di bulan terakhir dengan per bulan hanya memberikan nisbah bagi hasil saja

b. Penerapan strategi pemasaran akad pada BPRS Al Salaam dengan menggunakan konsep 4P yaitu Product, Place, Price dan Promotion agar dapat diterima dimasyarakat dan dapat diaplikasikan oleh masyarakat dalam menggunakan akad mudharabah di BPRS.

Manajemen Pemasaran. Vol, 1. No, 2. Hal 2

Dwi Permata, Russely Inti. Yaningwati. Fransisca. Z.A, Zahroh. (2014). Analisis Pengaruh Pembiayaan Mudharabah Dan Musyarakah Terhadap Tingkat Profitabilitas (Return On Equity) (Studi Pada Bank Umum Syariah Yang Terdaftar Di Bank Indonesia Periode 2009-2012). Jurnal Administrasi Bisnis (JAB). Vol. 12, No. 1 Hal 3

Eka satyarini noermawati Julia, (2017). Analisis faktor yang menjadi alasan Nasabah memilih Deposito Mudharabah di BPRS XYZ. Yogyakarta. Jurnal Ekonomi Syariah Indonesia. Vol 7 No 2. Hal 2-3

Entaresmen, R. Ajeng. (2016). Strategi Pemasaran Terhadap Penjualan Produk Tabungan Ib Hasanah Di Pt. Bank Negara Indonesia Syariah Kantor Cabang X. Jurnal Manajemen dan Pemasaran Jasa. Vol. 9 No. 1 Hal 62

Erni Susana, Prasetyanti Annisa. (2011). Pelaksanaan dan Sistem Bagi Hasil Pembiayaan Al-Mudharabah pada Bank Syariah. Malang. Jurnal 
Keuangan dan Perbankan, Vol. 15, No.3

Fadhilah, Novi. (2015). Analisis Pembiayaan Mudharabah Dan Murabahah Terhadap Laba Bank Syariah Mandiri. Jurnal Riset Akuntansi Dan Bisnis, Vol. 15, No. 1, Hal 65-67

Gina, Widya. Effendi, Jaenal. (2014). Program Pembiayaan Lembaga Keuangan Mikro Syariah (LKMS) dalam Peningkatan Kesejahteraan Pelaku Usaha Mikro (Studi Kasus BMT Baitul Karim Bekasi). Jurnal Al-Muzara'ah, Vol. 3, No. 1, Hal 3334

Harrieti, Nun. (2017). Pelaksanaan Akad Mudharabah Muqayyadah Off Balance Sheet Pada Perbankan Syariah Dan Pengaturannya Di Indonesia. Jurnal Hukum Positium. Vol. 1, No. 2, Hal 247

Kusuma Dewi, Ernanda. Astari, Ayu. (2017). Peran Pembiayaan Mudharabah Dalam Pengembangan Kinerja Usaha Mikro Pada Bmt (Baitul Maal Wat Tamwil). Jurnal Law and Justice Vol. 2 No. 2 Hal 117-120

Mauludi AC, Ali. (2015). Akuntansi Pembiayaan Mudharabah. Jurnal Iqtishadiah. Vol. 2, No. 2, Hal 132

Muklis, Fauziah, Siti. (2015). Mudharabah, Murabahah, dan Musyarakah Pengaruhnya Terhadap Laba
Bersih BUS di Indonesia. Jurnal Islaminomic, Vol. 6 No. 2 Hal 117

Paramita, Metti. (2017). Analisis Sistem Pengembangan Sumber Daya Manusia Di Lembaga Keuangan Mikro Syariah. Jurnal Syarikah Vol. 3 No. 2, Hal. 496

Sapudin, Ahmad. Najib, Mukhamad, Djihar, Setiadi. (2017). Strategi Pengembangan Lembaga Keuangan Mikro Syariah (Studi Kasus pada BMT Tawfin Jakarta). Jurnal Al-Muzara'ah Vol.5, No.1 Hal 23

Susana, Erni. Prasetyanti, Annisa P. (2011). Pelaksanaan Dan Sistem Bagi Hasil Pembiayaan AlMudharabah Pada Bank Syariah. Jurnal Keuangan dan Perbankan, Vol.15, No.3, Hal 468

Srisusilawati, Popon. Eprianti, Nanik. (2017). Penerapan Prinsip Keadilan Dalam Akad Mudharabah Di Lembaga Keuangan Syariah. Jurnal Law and Justice Vol. 2 No. 1 Hal 16

Ratna, Ai. (2018). Strategi Pemasaran Produk Pembiayaan Murabahah Di Bank Syariah Mandiri. Jurnal Econosy. Vol, 1. No, 1.

Waluyo, Bambang. (2016). Implementasi Pembiayaan Mudharabah Pada Bank Syariah Untuk Merealisasikan Tujuan Ekonomi Islam. Jurnal Ekonomi dan Bisnis Islam, Vol. 2, No. 2 Hal 188 